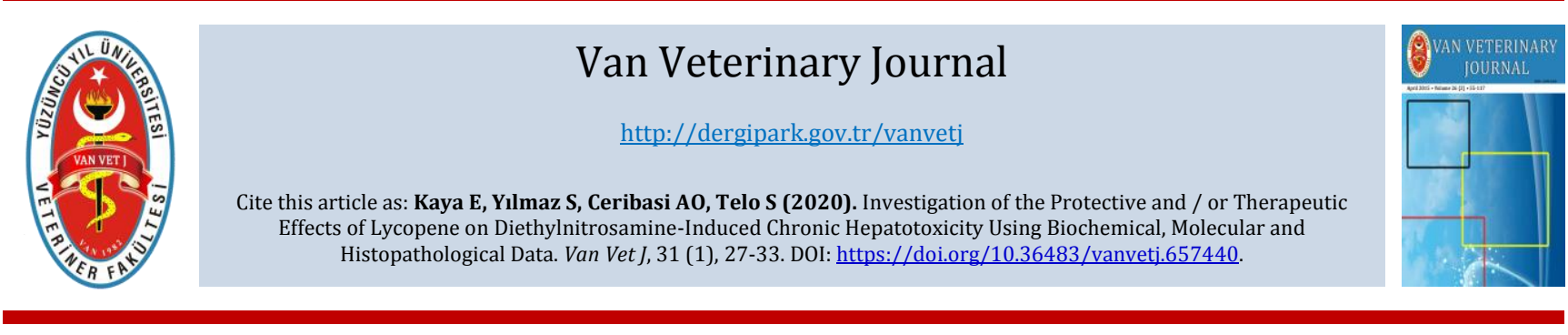

ISSN: 2149-3359

Original Article

e-ISSN: $2149-8644$

\title{
Investigation of the Protective and / or Therapeutic Effects of Lycopene on Diethylnitrosamine-Induced Chronic Hepatotoxicity Using Biochemical, Molecular and Histopathological Data
}

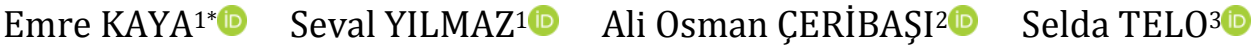 \\ ${ }^{1}$ Firat University, Faculty of Veterinary Medicine, Department of Biochemistry, Elazig, Turkey \\ 2 Firat University, Faculty of Veterinary Medicine, Department of Pathology, Elazig, Turkey \\ ${ }^{3}$ Firat University, Faculty of Dentistry, Department of Basic Science, Elazig, Turkey
}

Received: 12.12 .2019

Accepted: 27.01.2020

\begin{abstract}
The aim of the study is to investigate the role of lycopene on diethylnitrosamine (DEN)-induced chronic hepatotoxicity using biochemical, molecular and histopathological approaches. Thirty five male Wistar albino rats were assigned into five groups of 7 rats each. Groups were formed as control, lycopene, DEN, lycopene+DEN and DEN+lycopene. Lycopene was applied to rats every other day at $10 \mathrm{mg} / \mathrm{kg} / \mathrm{bw}$, gavage for 10 days. DEN was applied intraperitoneally to rats at a single dose, $200 \mathrm{mg} / \mathrm{kg} / \mathrm{bw}$ for 90 days. Lycopene administration was started 10 days before the DEN administration in lycopene+DEN group, together with the DEN administration in DEN+lycopene group. The study was terminated 90 days after DEN administration. DEN caused the oxidative stress by the increased malondialdehyde level and the decreased reduced glutathione level, antioxidant enzyme activities $(\mathrm{p}<0.001)$. Lycopene administration improved the biochemical indices of both blood and liver tissue compared to the DEN group. RT-PCR analysis revealed that the catalase enzyme in the DEN group increased expression levels. Histopathologically, many histopathologic changes such as karyomegaly, necrosis and hydropic degeneration were observed in the liver tissues of the DEN and lycopene+DEN groups. Both biochemical and histopathological results showed that healing of DEN+lycopene group was better than lycopene+DEN group. These results suggest that besides the protective effects, the therapeutic effect of lycopene is due to its antioxidant effects on DEN-induced hepatotoxicity.
\end{abstract}

Keywords: Antioxidant, Diethylnitrosamine, Lycopene, Malondialdeyhde, CAT Enzyme Expression

\section{ÖZ \\ Biyokimyasal, Moleküler ve Histopatolojik Veriler Kullanılarak Likopenin Dietilnitrozamine Bağlı Kronik Hepatotoksisite Üzerine Koruyucu ve / veya Tedavi Edici Etkilerinin Araştırılması}

Çalışmanın amacı, likopenin dietilnitrozamin (DEN) kaynaklı kronik hepatotoksisite üzerindeki rolünü biyokimyasal, moleküler ve histopatolojik yaklaşımları kullanarak araştırmaktır. 35 adet erkek Wistar albino rat, her grupta 7 rat olacak şekilde 5 gruba ayrılmıştır. Gruplar, kontrol, likopen, DEN, likopen+DEN ve DEN+likopen şeklinde oluşturulmuştur. Likopen, gün aşırı olarak $10 \mathrm{mg} / \mathrm{kg} /$ vücut ağırlığı dozunda gavaj yoluyla 10 gün uygulanmıștır. DEN, ratlara $200 \mathrm{mg} / \mathrm{kg}$ vücut ağırlığı dozunda intraperitoneal olarak tek doz 90 gün uygulanmıştır. Likopen uygulaması, likopen+DEN grubunda DEN uygulamasından 10 gün önce, DEN+likopen grubunda ise DEN uygulaması ile birlikte başlamıştır. DEN uygulamasından 90 gün süre sonra çalışma sonlandırılmıştır. DEN, dokularda malondialdehid düzeylerinde artışa, redükte glutatyon düzeyi ve antioksidan enzim aktivitelerinde düşüşe sebep olarak oksidatif strese neden olmuştur $(\mathrm{p}<0,001)$. Likopen uygulaması hem kan hem de karaciğer dokusunda DEN grubuna kıyasla biyokimyasal endekslerde iyileşme sağlamıştır. RT-PCR analizlerinde DEN grubundaki katalaz enziminin ekspresyon düzeylerini arttırdığı belirlenmiştir. Histopatolojik olarak, DEN ve likopen+DEN gruplarının karaciğer dokularında karyomegali, nekroz ve hidropik dejenerasyon gibi birçok histopatolojik değișiklikler gözlenmiștir. Hem biyokimyasal hem de histopatolojik sonuçlarda DEN+likopen grubundaki iyileşmesinin likopen+DEN grubundan daha iyi olduğu gözlenmiştir. Bu sonuçlar, likopenin koruyucu etkisinden ziyade tedavi edici etkisinin DEN'e bağlı hepatotoksisitede likopenin antioksidan etkisine bağlı kaynaklandı̆̆ını göstermektedir.

Anahtar Kelimeler: Antioksidan, Dietilnitrozamin, Likopen, Malondialdehid, KAT Enzim Ekspresyonu 


\section{INTRODUCTION}

Nitrosamines and nitroso compounds are one of the most important chemicals and adversely affect human health and can cause tumor formation. They exhibit this activity mainly by interacting with nucleic acids and proteins (Jahan et al. 2007). The dose, frequency of exposure, and method of administration of the nitrosamines may affect different organs (e.g. lung, kidney or liver) and may lead to tumor formation (Lijinsky and Kovatch 1989; Lijinsky 1992). Toxic effects of nitrosamines, particularly diethylnitrosamine (DEN), are primarily seen in the blood and liver. Most drugs lead to nitrosamine formation and increase of cancerous cells in the liver when used with sodium nitrite. Furthermore, other organs where blood flow is high, such as kidneys, are also affected at a lower dose than the liver (Yllmaz et al. 2008).

DEN is a carcinogenic substance, widely used in experimental animal models. DEN causes degenerative, proliferative, and neoplastic lesions in the liver (Gayathri et al. 2009). DEN is hydroxilated in the liver by cytochrome P-450 isoenzymes and becomes bioactivated by alkylation mechanism. Activation results in the production of radical metabolites, mainly ethyl radical $\left(\mathrm{CH}_{3} \mathrm{CH}_{2}\right.$.) (Lijinsky 1992). DEN increases reactive oxygen species (ROS), and by this way leads to cell damage and oxidative stress. The generation of ROS may be responsible for the carcinogenic effects of DEN (Yamada et al. 2006; Gayathri et al. 2009). High intracellular levels of ROS lead to mitochondrial damage, DNA modification, and lipid peroxidation (LPO), resulting in many diseases, including cancer (Yamada et al. 2006; Pradeep et al. 2007). The metabolites of DEN mediate the binding of tumor promoters by covalently binding to the DNA with one or two oxidation-providing electrons. The tumor promoter causes the formation of reactive oxygen molecules and hydrogen peroxide $\left(\mathrm{H}_{2} \mathrm{O}_{2}\right)$ by acting as a superoxide radical $\left(\mathrm{O}_{2 .}\right.$ ) inducer (Yamada et al. 2006; Pradeep et al. 2007).

Lycopene have anticarcinogenic, anti-inflammatory and antioxidant effects. The relationship between free oxygen radicals and lycopene is as follows: adding a new radical to the free radical, neutralizing the radical by removing a hydrogen atom from its structure, and neutralizing the radical by transferring an electron from structure of the free radical (El-Agemey et al. 2004). Lycopene can protect cells against oxidative stress by acting together with various mechanisms (e.g. singlet oxygen scavenger) as an antioxidant. Before being reduced, a molecule of lycopene can bind thousands of singlet oxygen molecules (Krinsky 1988). Its effectiveness in capturing singlet oxygen depends on conjugated double bonds number it mainly contains (Ukai et al. 1994).

The aim of the study was to determine the possible protective and / or therapeutic effects of lycopene on DENinduced oxidative damage and CAT expression in the blood and liver tissues using biochemical, molecular and histopathological approaches in rats.

\section{MATERIALS and METHODS}

\section{Animals and experimental groups}

A total of 35 male Wistar-Albino rats (weighing 250-300 g, aged 3 months) were used in this study. Ethics committee approval was obtained from Firat University Local Ethics Committee for Animal Experiments (2014/18). The animals to be used in the study were obtained from the Firat University Experimental Research Center.
The experimental applications were conducted conveniently with the conditions for the care and use of laboratory animals (12 hours light; 12 hours darkness; $24 \pm 3^{\circ} \mathrm{C}$ ). During the experimental applications, the rats were provided the commercial rat feed (pellet feed) and tap water ad libitum.

The animals were randomly divided into five experimental groups, including seven rats in each. These groups were arranged as follows: control group (not treated), lycopene group (lycopene was administered), DEN group (a single dose of DEN was administered), lycopene+DEN (lycopene was started 10 days before the DEN administration), DEN+lycopene group (DEN and lycopene were administered together).

Lycopene was suspended in corn oil and it was administered to the animals by gavage every other day at the dose of $10 \mathrm{mg} / \mathrm{kg}$ body weight for 10 days. DEN was administered the animals a single intraperitoneal (i.p.) dose at the dose of $200 \mathrm{mg} / \mathrm{kg}$ body weight dissolved in serum physiological $(0.9 \% \mathrm{NaCl})$ for 90 days. The doses of DEN (El-Shahat et al. 2012) and lycopene (Kumar ve Kumar 2009) used in this study was selected according to previous studies.

\section{Sample collection}

Following the applications, rats were sacrificed and tissue samples were obtained from blood and liver. Blood samples were collected in tubes containing anticoagulant (ethylenediaminetetraacetic acid [EDTA]) and centrifuged for $10 \mathrm{~min}$ at $3000 \mathrm{rpm}$ at $+4^{\circ} \mathrm{C}$ to separate plasma. Autoanalyser (Advia 1800 Chemistry Analyser, Siemens Healthineers, Germany) was used to determine the aspartate transaminase (AST), alanine transaminase (ALT), alkaline phosphatase (ALP), lactate dehydrogenase (LDH) enzyme activities. Before starting the analyses, liver tissues were washed with saline and then diluted 1:10 with distilled water and homogenized in a Potter-Elvehjem homogenizer. Homogenates were centrifuged at $3500 \mathrm{rpm}$ for $15 \mathrm{~min}$ for malondialdehyde (MDA), reduced glutathione (GSH), CAT, glutathione-S-transferase (GST) and superoxide dismutase (SOD) analysis and at 14000 $\mathrm{rpm}$ for $55 \mathrm{~min}$ for glutathione peroxidase (GSH-Px) analysis.

For the reverse transcription-polymerase chain reaction (RT-PCR) analyses, blood and liver samples were taken into tubes containing RNA stabilization solution and stored at $-80^{\circ} \mathrm{C}$ until the study was performed.

\section{Biochemical analysis}

MDA and GSH levels, CAT, GSH-Px, GST, SOD activities, protein, hemoglobin levels were determined by spectrophotometric methods in tissue samples.

The MDA level was tested according to the method described by Placer et al. (1966). This method was based on the reaction of thiobarbituric acid (TBA) with MDA, one of the aldehyde products of lipid peroxidation. The GSH level was determined by the method of Ellman et al. (1961). This method was a spectrophotometric method based on the formation of highly stable yellow colour of sulphhydryl groups when 5,5'dithiobis-2-nitrobenzoic acid (DTNB) was added.

The CAT activity was carried out by using Aebi's method (1984). It was determined by measuring the resolution of $\mathrm{H}_{2} \mathrm{O}_{2}$ at $240 \mathrm{~nm}$. The GSH-Px activity was determined by the Beutler method (1984). GSH-Px catalyses the oxidation of GSH to oxide glutathione (GSSG) using $\mathrm{H}_{2} \mathrm{O}_{2}$. 
The method described by Habig et al. (1974) was utilised to test GST activity. The enzyme activity was determined by measuring the amount of enzyme catalysing $1 \mu \mathrm{mol}$ of 1-(S-glutathionyl)-2.4 dinitrobenzene per minute at 340 $\mathrm{nm}$ at $37^{\circ} \mathrm{C}$ using GSH and 1-chloro-2,4-dinitrobenzene. The SOD activity was tested by quantifying $\mathrm{O}_{2}-$ generated by xanthine and xanthine oxidases reacting with nitroblue tetrazolium (Sun et al. 1988). In the determination of hemoglobin level, Frankel et al. (1970) method is used. The protein concentration was determined using the method described by Lowry et al. (1951).

\section{Total RNA isolation and gene expression analysis}

Both blood and liver were processed based on the method of Rotimi et al. (2017). Blood samples were placed into RNAprotect ${ }^{\circledR}$ animal blood tubes containing stabilization reagent; whereas, liver tissues were preserved in RNAlater. The gene expression levels of CAT enzyme was assessed using semi-quantitative reverse transcriptase polymerase chain reaction (RT-PCR). RNA was extracted from the blood using an RNAprotect ${ }^{\circledR}$ animal blood kit (Qiagen, Germany). RNA was extracted from liver using an RNeasy ${ }^{\circledR}$ Plus Mini Kit according to the manufacturer's protocol. cDNA was obtained from RNA samples via a Reverse Transcription System Kit (First Strand Kit, Qiagen, Germany) as well as an Applied Biosystem, 7500 Fast RTPCR System.

The RNA samples were incubated for 15 minutes at $42^{\circ} \mathrm{C}$, as well as for 5 minutes at $95^{\circ} \mathrm{C}$ for cDNA synthesis in accordance with the manufacturer's protocol. The gene specific primers (rat CAT primer (NM_012520)) for RTPCR were obtained from Qiagen. Reactions were prepared in $25 \mu \mathrm{l}$ volumes by the SYBR Green Master Mix (Qiagen, Germany). The cycling conditions were performed according to the manufacturer's protocol as follows: 15 minutes at $95^{\circ} \mathrm{C}, 15$ seconds at $95^{\circ} \mathrm{C}$, and 1 minute at $60^{\circ} \mathrm{C}$ (repeated for 40 cycles). The RT-PCR analysis results were then normalized against the expression level of the internal control $\beta$-Actin (NM_031144). The values of all the samples were expressed as percentages with respect to the control.

\section{Histopathological examination}

Following necropsies, liver tissue samples were fixed in $10 \%$ neutral buffered formalin, were embedded in paraffin and cut at a thickness of $5 \mu \mathrm{m}$. Then, they were stained with Hematoxylin and Eosin (H\&E). After that, 10 random microscopic areas were examined at $\times 40$ magnification. The changes were rated to be none (0), mild (1), moderate (2), and severe (3) (Luna, 1968).

\section{Statistical analysis}

Shapiro-Wilk normality test was applied to determine whether the raw values of all the measured parameters showed normal distribution and as a result of the test, it was determined that the values in all parameters showed normal distribution. Based on the result of this test, oneway analysis of variance (ANOVA) was used to determine differences between groups, and post hoc Tukey test for paired comparisons.

All statistical analyses were performed using SPSS version 22.0 software (IBM Corporation, Armonk, NY, USA). The data obtained as a result of the study are expressed as mean and standard error. A p value of $<0.05$ was considered statistically significant.

\section{RESULTS}

\section{MDA, GSH levels, and antioxidant enzyme activities}

Tables 1 and 2 show the MDA, GSH levels and CAT, GSH-Px, GST and SOD activities in blood and liver tissues. When the DEN treated group was compared with the control group, an increase was observed in the MDA levels and a decrease in GSH levels, CAT, GSH-Px, GST and SOD activities in blood and liver tissue samples $(\mathrm{p}<0.001)$. When the DEN group was compared with the group in which lycopene was started before DEN administration (lycopene+DEN group) and group in which lycopene was started together with DEN administration (DEN+lycopene group), MDA levels were found to decrease whereas GSH levels, CAT, GSH-Px, GST and SOD activities were found to increase in the blood tissue and the values of the DEN administered groups approached the values of the control group $(\mathrm{p}<0.001)$. Similar changes were observed in the liver tissue and the changes were found to be more significant in the group in which lycopene was given with DEN administration (DEN+lycopene group).

\section{CAT enzyme gene expression levels}

Figures 1 and 2 show CAT enzyme gene expression levels in blood and liver tissues. The CAT enzyme gene expression levels were found to be significantly higher in the liver tissues of the DEN treated group compared to those of the control group, however, there was no statistically significant change in blood tissue compared to the control group. A significant decrease was observed in the expression levels in the liver tissue in the lycopene supplemented groups (lycopene+DEN and DEN+lycopene groups) compared to the DEN group and this decrease was found to be higher in DEN+lycopene group.

\section{AST, ALT, ALP and LDH activities}

Plasma AST, ALT, ALP, LDH activities are given in Table 3. A statistically significant increase was observed in all values in the DEN group compared to the control group $(\mathrm{p}<0.05$ and $\mathrm{p}<0.001)$. When the lycopene+DEN group and DEN group were compared, no difference was observed in the lycopene+DEN group in terms of AST and ALP activities whereas ALT, LDH activities decreased and approached to the control group values. In the DEN+lycopene group, there was a decrease in AST, ALT, LDH activities compared to the DEN group, but there was no change in ALP activity.

\section{Histopathological results}

Microscopic lesions and scoring values of control and experimental groups are given in Table 4. While the severity and distribution varied according to groups, the most significant microscopic changes were generally as follows: cloudy swelling, necrotic changes characterized by karyopyknosis, karyomegaly and apoptosis in hepatocytes and disorganization, sinusoidal and portal congestion, periportal cell infiltration, intra- and extra-cellular bile pigment accumulations, and Kupffer cell hyperplasia on the hepatic cord. The most severe microscopic changes were observed in DEN and lycopene+DEN groups. In the DEN+lycopene group, it was noted that there was a decrease in the severity of degenerative changes in the liver compared to the DEN group. 
Table 1. Effects of Lycopene on MDA and GSH levels and CAT, GSH-Px, SOD activities in blood tissue of DEN treated rats.

\begin{tabular}{llllll}
\hline & Control & Lycopene & DEN & Lyco.+DEN & DEN+Lyco. \\
\hline MDA (nmol/ml) & $8,34 \pm 0,04^{\mathrm{ab}}$ & $8,00 \pm 0,10^{\mathrm{a}}$ & $11,50 \pm 0,17^{\mathrm{c}}$ & $8,57 \pm 0,10^{\mathrm{b}}$ & $8,79 \pm 0,14^{\mathrm{b}}$ \\
GSH ( $\mu \mathrm{mol} / \mathbf{m l})$ & $47,21 \pm 0,22^{\mathrm{a}}$ & $47,01 \pm 0,40^{\mathrm{a}}$ & $36,03 \pm 0,84^{\mathrm{c}}$ & $45,58 \pm 0,38^{\mathrm{a}}$ & $45,60 \pm 0,38^{\mathrm{a}}$ \\
CAT (k/g Hb) & $65,33 \pm 0,78^{\mathrm{a}}$ & $65,22 \pm 0,52^{\mathrm{a}}$ & $44,37 \pm 0,63^{\mathrm{d}}$ & $62,81 \pm 0,99^{\mathrm{a}}$ & $61,84 \pm 1,40^{\mathrm{a}}$ \\
GSH-Px (U/g Hb) & $86,07 \pm 1,74^{\mathrm{a}}$ & $82,41 \pm 2,11^{\mathrm{a}}$ & $60,63 \pm 2,74^{\mathrm{b}}$ & $78,55 \pm 2,43^{\mathrm{a}}$ & $79,16 \pm 0,41^{\mathrm{a}}$ \\
SOD (U/g Hb) & $72,93 \pm 0,49^{\mathrm{a}}$ & $72,01 \pm 0,44^{\mathrm{a}}$ & $65,84 \pm 0,67^{\mathrm{b}}$ & $71,52 \pm 0,41^{\mathrm{a}}$ & $72,34 \pm 0,33^{\mathrm{a}}$ \\
\hline
\end{tabular}

The data are expressed in mean \pm S.E. for seven animals per group. Within rows, means with different letters (a, b, c, and d) are significantly different.

Table 2. Effects of lycopene on MDA and GSH levels and CAT, GSH-Px, GST, SOD activities in liver tissue of DEN treated rats.

\begin{tabular}{lccccc}
\hline & Control & Lycopene & DEN & Lyco.+DEN & DEN+Lyco. \\
\hline MDA (nmol/g doku) & $0,63 \pm 0,01^{\mathrm{abc}}$ & $0,61 \pm 0,01^{\mathrm{a}}$ & $0,93 \pm 0,02^{\mathrm{d}}$ & $0,68 \pm 0,01^{\mathrm{c}}$ & $0,65 \pm 0,01^{\mathrm{abc}}$ \\
GSH ( $\boldsymbol{\mu m o l} / \mathbf{m l})$ & $17,12 \pm 0,23^{\mathrm{a}}$ & $17,08 \pm 0,10^{\mathrm{a}}$ & $15,10 \pm 0,07^{\mathrm{c}}$ & $16,39 \pm 0,05^{\mathrm{b}}$ & $16,93 \pm 0,05^{\mathrm{a}}$ \\
CAT (k/mg protein) & $0,378 \pm 0,01^{\mathrm{a}}$ & $0,381 \pm 0,01^{\mathrm{a}}$ & $0,183 \pm 0,01^{\mathrm{c}}$ & $0,332 \pm 0,02^{\mathrm{a}}$ & $0,335 \pm 0,01^{\mathrm{a}}$ \\
GSH-Px (U/g rotein) & $34,19 \pm 1,31^{\mathrm{a}}$ & $35,07 \pm 0,88^{\mathrm{a}}$ & $28,43 \pm 1,11^{\mathrm{b}}$ & $32,61 \pm 1,06^{\mathrm{a}}$ & $32,28 \pm 1,59^{\mathrm{a}}$ \\
GST (U/mg protein) & $20,92 \pm 0,28^{\mathrm{a}}$ & $20,56 \pm 0,46^{\mathrm{a}}$ & $17,44 \pm 0,26^{\mathrm{c}}$ & $19,37 \pm 0,23^{\mathrm{b}}$ & $19,96 \pm 0,30^{\mathrm{ab}}$ \\
SOD (U/mg protein) & $0,646 \pm 0,01^{\mathrm{a}}$ & $0,645 \pm 0,01^{\mathrm{a}}$ & $0,629 \pm 0,01^{\mathrm{c}}$ & $0,643 \pm 0,01^{\mathrm{a}}$ & $0,639 \pm 0,01^{\mathrm{ab}}$ \\
\hline
\end{tabular}

The data are expressed in mean \pm S.E. for seven animals per group. Within rows, means with different letters (a, b, c, and d) are significantly different.

Table 3. Effects of lycopene on AST, ALT, ALP, LDH activities in plasma of DEN administrated rats.

\begin{tabular}{lccccc}
\hline & Control & Lycopene & DEN & Lyco.+DEN & DEN+Lyco. \\
\hline AST (U/L) & $171,00 \pm 5,77^{\mathrm{ab}}$ & $146,33 \pm 2,87^{\mathrm{a}}$ & $225,00 \pm 5,97^{\mathrm{d}}$ & $242,50 \pm 5,71^{\mathrm{d}}$ & $189,66 \pm 12,51^{\mathrm{bc}}$ \\
ALT(U/L) & $78,25 \pm 6,10^{\mathrm{a}}$ & $83,75 \pm 2,32^{\mathrm{ab}}$ & $96,00 \pm 2,22^{\mathrm{bc}}$ & $88,71 \pm 5,62^{\mathrm{ab}}$ & $87,50 \pm 6,63^{\mathrm{ab}}$ \\
ALP(U/L) & $6,50 \pm 0,22^{\mathrm{a}}$ & $7,00 \pm 0,28^{\mathrm{a}}$ & $15,00 \pm 0,88^{\mathrm{b}}$ & $14,33 \pm 2,92^{\mathrm{b}}$ & $13,50 \pm 2,46^{\mathrm{b}}$ \\
LDH(U/L) & $794,00 \pm 49,07^{\mathrm{ab}}$ & $724,57 \pm 63,34^{\mathrm{a}}$ & $1363,20 \pm 73,63^{\mathrm{c}}$ & $980,66 \pm 27,79^{\mathrm{b}}$ & $853,00 \pm 28,98^{\mathrm{ab}}$ \\
\hline
\end{tabular}

The data are expressed in mean \pm S.E. for seven animals per group. Within rows, means with different letters (a, b, c, and d) are significantly different.

Table 4. Microscopic lesions observed in liver of DEN treated rat.

\begin{tabular}{|c|c|c|c|c|c|}
\hline & Control & Lycopene & DEN & Lyco.+DEN & DEN+Lyco. \\
\hline Karyomegaly & $0.14 \pm 0.0^{\mathrm{a}}$ & $0.14 \pm 0.0^{\mathrm{a}}$ & $2.00 \pm 0.31^{b c}$ & $2.14 \pm 0.34^{c}$ & $1.86 \pm 0.14^{\mathrm{b}}$ \\
\hline Sinusoidal Congestion & $0.57 \pm 0.20^{a}$ & $1.00 \pm 0.0^{\mathrm{b}}$ & $2.00 \pm 0.0 \mathrm{c}$ & $1.71 \pm 0.18^{\mathrm{bc}}$ & $2.00 \pm 0.0^{c}$ \\
\hline Karyopyknosis & $0.14 \pm 0.0^{\mathrm{a}}$ & $0.14 \pm 0.0^{\mathrm{a}}$ & $1.57 \pm 0.20^{\mathrm{b}}$ & $2.00 \pm 0.0^{c}$ & $1.29 \pm 0.18^{b}$ \\
\hline Cloudy Swelling (Periasiner) & $0.0 \pm 0.0^{\mathrm{a}}$ & $0.44 \pm 0.20^{b}$ & $3.00 \pm 0.0^{c}$ & $3.00 \pm 0.0^{c}$ & $1.71 \pm 0.18^{\mathrm{bc}}$ \\
\hline Single Cell Necrosis & $0.0 \pm 0.0^{\mathrm{a}}$ & $0.57 \pm 0.20^{a}$ & $2.57 \pm 0.20^{b}$ & $2.71 \pm 0.18^{b}$ & $1.43 \pm 0.18^{\mathrm{ab}}$ \\
\hline Fatty Degeneration & $0.14 \pm 0.14^{\mathrm{a}}$ & $0.0 \pm 0.0^{\mathrm{a}}$ & $1.00 \pm 0.0^{\mathrm{ab}}$ & $1.00 \pm 0.0^{\mathrm{ab}}$ & $1.00 \pm 0.0^{\mathrm{ab}}$ \\
\hline Bile Duct Proliferation & $0.0 \pm 0.0^{a}$ & $0.14 \pm 0.0^{\mathrm{a}}$ & $2.00 \pm 0.0^{c}$ & $1.00 \pm 0.0^{\mathrm{b}}$ & $1.00 \pm 0.0^{\mathrm{b}}$ \\
\hline Apoptotic Bodies & $0.14 \pm 0.0^{\mathrm{a}}$ & $0.14 \pm 0.0^{\mathrm{a}}$ & $2.00 \pm 0.0 \mathrm{c}$ & $1.00 \pm 0.0^{\mathrm{b}}$ & $1.00 \pm 0.0^{b}$ \\
\hline Kupffer Cell Activation & $0.0 \pm 0.0^{\mathrm{a}}$ & $0.0 \pm 0.0^{\mathrm{a}}$ & $0.43 \pm 0.20^{\mathrm{ab}}$ & $1.00 \pm 0.0^{\mathrm{b}}$ & $1.00 \pm 0.0^{b}$ \\
\hline Periportal Cell Infiltration & $0.57 \pm 0.20^{a}$ & $0.71 \pm 0.18^{\mathrm{a}}$ & $1.43 \pm 0.20^{b}$ & $1.29 \pm 0.18^{b}$ & $1.00 \pm 0.0^{\mathrm{ab}}$ \\
\hline Hepatic Cord Disorganization & $0.29 \pm 0.18^{a}$ & $0.29 \pm 0.18^{a}$ & $2.57 \pm 0.20^{c}$ & $2.00 \pm 0.31 \mathrm{bc}$ & $2.00 \pm 0.21 \mathrm{bc}$ \\
\hline Portal Congestion & $1.00 \pm 0.0^{\mathrm{a}}$ & $1.00 \pm 0.0^{\mathrm{a}}$ & $1.29 \pm 0.18^{b}$ & $1.43 \pm 0.20^{b}$ & $1.43 \pm 0.20^{b}$ \\
\hline Bile Pigment Accumulations & $0.0 \pm 0.0$ & $0.0 \pm 0.0$ & $1.00 \pm 0.0$ & $1.00 \pm 0.0$ & $1.00 \pm 0.0$ \\
\hline
\end{tabular}

The data are expressed in mean \pm S.E. for seven animals per group. Within rows, means with different letters (a,b, and c) are significantly different $(\mathrm{p}<0.001)$. 


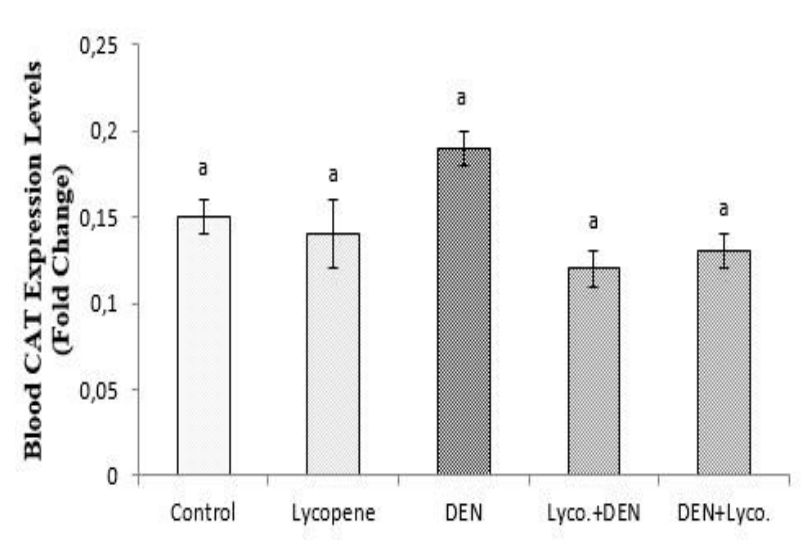

Figure 1. The effect of lycopene supplementation on blood CAT expression level.

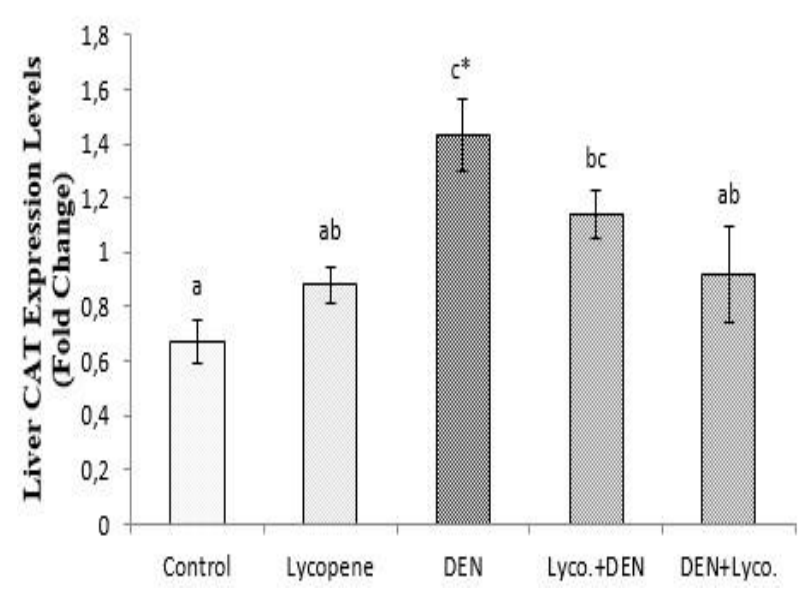

Figure 2. The effect of lycopene supplementation on liver CAT expression level $(* \mathrm{P}<0.001)$.

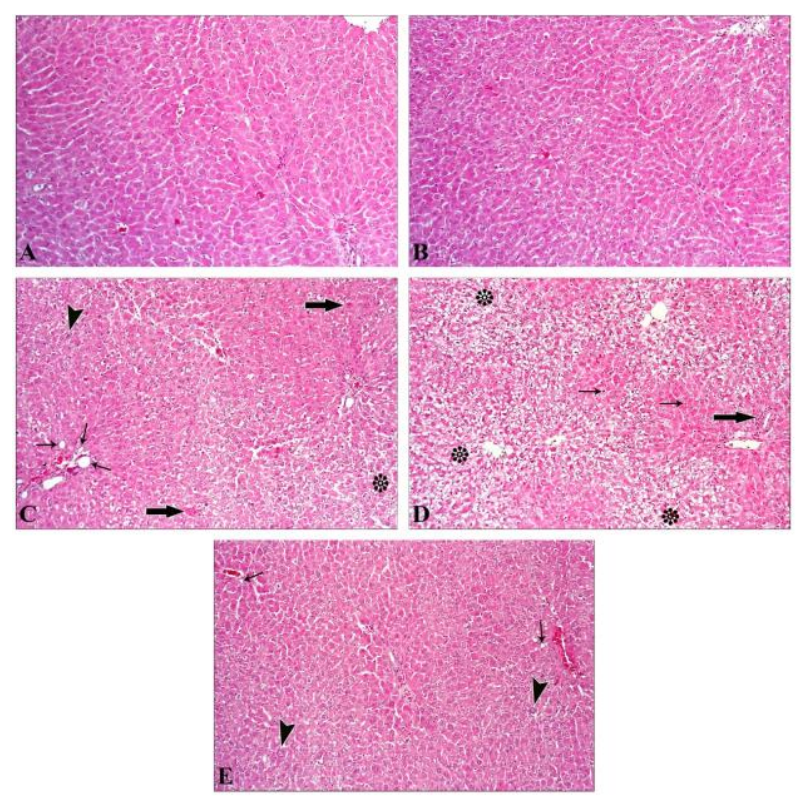

Figure 3. Light microscopic view of the liver of DENtreated rats. A. Control Group, normal appearanced liver structure. B. Lycopene Treated Group, normal appearanced liver structure. C. DEN Treated Group, karyomegaly (arrowhead), necrosis-necrotic changes $\left(^{*}\right.$ ), single cell necrosis (thick arrow), bile duct proliferation (thin arrow). D. Lycopene+DEN Treated Group, cloudy swelling $(*)$, periportal cell infiltration (thick arrow), apoptotic bodies (thin arrow). E. DEN+Lycopene Treated Group, karyomegaly (arrowhead), fatty degeneration (thin arrow). (H-E staining, magnification $\mathrm{x} 40$ ).

\section{DISCUSSION}

The free radical formation may be suggested as the main mechanism of hepatotoxicity although many opinions have been reported in the pathogenesis of DEN-induced toxicity. If the generation of free radicals exceeds the protective effects of the defense system, they adversely affect metabolism. The increase in the MDA level is an important sign of oxidative stress (Gaweł et al. 2004). In the present study, the increase in MDA levels in plasma and liver tissues obtained from rats in the DEN group can be considered as an indicator of the DEN-induced damage. This increase may be further related to the metabolism of DEN, which reacts with cellular components, particularly with polyunsaturated fatty acids, in the cell membrane and causes the release of iron ions that increases the MDA levels. GSH prevents the peroxidation, protects cell membranes and allows the removal of free radicals (Farombi and Fakoya 2005). In the present study, the decrease observed in the GSH levels in blood and liver tissues of the rats in the DEN group is attributed to DEN or its metabolites forming a conjugate with GSH to facilitate its excretion from the body. Furthermore, GSH plays a critical role in protecting tissues against the harmful effects of DEN and therefore, GSH consumption can also lead to significant decreases in GSH-Px activity. The decrease in GSH-Px activity following the DEN administration may be due to decreased levels of the relevant substrate (GSH) and ROS-induced changes in the protein structure (Farombi and Fakoya 2005; Halliwell and Gutteridge 2015)

In the present study, MDA levels in plasma and liver tissues were found to be significantly higher in the DEN group than in the control group. This indicates that DEN causes high levels of free radical formation that cannot be tolerated by the cellular antioxidant defense system. However, lycopene administration decreased the MDA level to the level in the control group, suggesting that lycopene may be effective in clearing free radicals, inhibiting LPO, and protecting membrane lipids against oxidative damage in plasma and liver of rats.

Antioxidant enzymes such as CAT and GSH-Px are the first line antioxidant defense system against ROS and their activities have been observed to decrease by DEN. The decrease in the CAT and GSH-Px activities due to the DENinduced oxidative stress may be due to the possible inhibitory effect of DEN-induced ROS on these enzymes, and decreased availability of GSH as a substrate while GSH-Px catalyzes the conversion of lipid peroxide to hydroxy acids in the presence of GSH (Farombi and Fakoya 2005; Halliwell and Gutteridge 2015). In the study, lycopene supplementation increases blood antioxidant activities and thus prevents the detrimental effects of peroxidation products.

In a study by Kim et al. (1997), in which different nitrosamines (DEN, N-methyl-N-nitrosourea, and 1,2dimethylhydrazine) were used in mice, the combination of DEN (10 mg/kg i.p.) with other nitrosamines has been reported to increase the neoplasia and oxidative stress in the lungs of mice at the end of 32 weeks. In a study by Pradeep et al. (2007), the effects of silymarin on DENinduced hepatotoxicity $(200 \mathrm{mg} / \mathrm{kg}$ i.p. $)$ has been investigated and authors have reported an increase in 
some liver-specific enzymes and LPO whereas there is a decrease in the antioxidant enzyme levels in the DEN group. In another study by the same authors investigating the effects of Cassina fistula on DEN-induced hepatotoxicity (100 mg/kg i.p.), they have reported that some liver-specific enzymes and LPO have increased whereas antioxidant enzyme levels have decreased, similar to their previous study (Pradeep et al. 2010).

In a study published in the literature, a significant decrease has been reported in gene expression levels of GST, CAT and GSH-Px enzymes in the DEN group in parallel with the decrease in antioxidant enzyme activities. The decrease in antioxidant enzyme activities and CAT gene expression after DEN administration has been attributed to the increase in the production of free radicals during DEN metabolism (Sayed-Ahmed et al. 2010). In a study by Bingül et al. (2015), a decrease has been reported in the CAT activity and expression levels in DEN treated rats. However, CAT enzyme expression levels were found to increase in groups treated with DEN in our study, contrary to other studies in the literature. The difference between CAT activity and expression level is thought to be due to the procedures performed after the post-translational transformations. There are studies, in which antioxidant compounds were used against oxidants in different tissues in oxidative stress, showing that these oxidant compounds increase (Kim et al. 2009) or decrease (Fustinoni-Reis et al. 2016) the CAT gene expression levels in particular among the antioxidant enzymes. Changes in the present study are thought to be caused by DEN-induced oxidative DNA damage in rat liver. Metabolites formed during the metabolism of DEN via cytochrome P-450 lead to oxidative, mutagenic and genotoxic damages in tissues.

In the present study, CAT enzyme activity in blood and liver tissues decreased significantly but the expression level of the same enzyme increased in DEN treated groups compared to the control group. The difference between CAT activity and gene expression level is thought to be due to variation in protein and mRNA transformation. Furthermore, the relationship between genotype and mRNA/protein levels can be also influenced by various factors such as environment and transcriptional regulation.

There are studies reporting that lycopene significantly changes LPO levels and antioxidant enzyme activities. In a study by Gupta et al. (2013) involving mice, the group received pretreatment with lycopene was compared with the DEN treated group and pretreatment with lycopene has been reported to have no significant effect on the activity of phase I enzymes, to decrease the LPO and GSH levels and to increase GSH-Px, GST and SOD activities. Blanche et al. (2013) have investigated the effects of Apo10 '-lycopenoic acid $(10 \mathrm{mg} / \mathrm{kg}$ diet $)$, a lycopene metabolite, in mice that were given DEN initially and fed with a high-fat diet for 24 weeks. They have observed a decrease in both the development of hepatic carcinogenesis and incidence of lung tumors. Abdallah et al. (2004) have investigated the protective effects of lycopene in DEN-induced (200 $\mathrm{mg} / \mathrm{kg}$ body weight) experimental hepatocarcinogenesis and hepatocellular carcinoma has been reported to develop in rats after six weeks and lycopene has been observed to inhibit the development of hepatocellular carcinoma. In rats that a single dose of DEN was administered intraperitoneally for 30 days, it was determined that lipid peroxidation levels and liver-specific enzyme activities were increased, and antioxidant enzyme activities and CAT enzyme expression levels were changed in compared to the control group. It was found that lipid peroxidation levels and increased liver-specific enzyme activities decreased and CAT enzyme expression levels approached control values in the group with lycopene application with DEN. It has been emphasized that lycopene exhibited an antioxidant property against DEN-induced LPO and related enzymes in rats (Kaya et al. 2019).

There are studies in the literature showing that pretreatment with lycopene is effective and pretreatment with lycopene has been reported to be effective $(\mathrm{Qu}$ et al. 2013). There are also studies showing that lycopene is effective when applied together with toxic substances (Yilmaz et al. 2006). In the present study, lycopene has been found to be more effective in DEN-induced hepatotoxicity in the group where it has been started together with DEN administration.

The increase in some liver-specific enzymes activities have a correlation with the number of cells transformed in the event of cancer (Jahan et al. 2007). Many studies have shown that DEN administration causes an increase in some liver-specific enzyme activities (Liu et al. 2005; Jahan et al. 2007; Shaarawy et al. 2009; Taha et al. 2010). In this study, DEN administration has significantly increased plasma AST, ALT, ALP, LDH activities, which is a sign of hepatocellular injury. This may be due to the rapid release of these enzymes from the cytoplasm into the bloodstream following the breakage of the plasma membrane and cellular damage.

\section{CONCLUSION}

Increased LPO levels and liver-specific enzyme activities and decreased enzymatic and non-enzymatic antioxidant levels are the signs of a liver injury. Moreover, elevated levels of CAT expression due to the increased oxidative stress are supportive. Considering the results of our study, it can be concluded that oxidative stress plays an important role in DEN-induced liver injuries. Furthermore, the effect of lycopene given together with DEN administration has been observed to be higher than the effect of lycopene given before DEN administration. Based on the biochemical, molecular and histopathological results of the study, the therapeutic effect of lycopene can be said to be more evident than its protective effect.

\section{ACKNOWLEDGEMENT}

We would like to thank FUBAP (VF.14.19) for financially supporting the study and this article is a part of the first author's doctoral thesis named "The Effect of Lycopene on Oxidative Stress and DNA Damage in Diethylnitrosamine Administered Rats".

\section{REFERENCES}

Abdallah IZ, Khattab HA (2004). Protective role of lycopene against diethylnitrosamine induced experimental hepatocarcinogenesis. Egypt J Hosp Med, 16 (1), 1-13.

Aebi H (1984). Catalase in vitro. Meth Enzymol, 105, 121-126.

Beutler E (1984). Red Cell Metabolism. In: A Manual of Biochemical Methods. Grune and Starton (Editors), 2nd Edition, 160, New York.

Bingül I, Başaran-Küçükgergin C, Aydın AF et al. (2016). Blueberry treatment attenuated cirrhotic and preneoplastic lesions and oxidative stress in the liver of diethylnitrosamine-treated rats. Int $J$ Immunopathol Pharm, 29(3), 426-437.

Blanche CIp, Hu KQ, Liu C, et al. (2013). Lycopene Metabolite, Apo-10'Lycopenoic acid, inhibits diethylnitrosamine-initiated, high fat dietpromoted hepatic inflammation and tumorigenesis in mice. Cancer Prev Res, 6 (12), 1304-1316. 
Ellman GL, Courtney KD, Andres V, Featherstone RM (1961). A new and rapid colorimetric determination of acetylcholinesterase activity. Biochem Pharmacol, 7, 88-95.

El-Agamey A, Lowe GM, McGarvey DJ, et al. (2004). Carotenoid radical chemistry and antioxidant/pro-oxidant properties. Arch Biochem Biophys, 430 (1), 37-48.

El-Shahat M, El-Abd S, Alkafafy M, El-Khatib G (2012). Potential chemoprevention of diethylnitrosamine-induced hepatocarcinogenesis in rats: Myrrh (Commiphora molmol) vs. turmeric (Curcuma longa). Acta Histochem, 114 (5), 421-428.

Farombi EO, Fakoya A (2005). Free radical scavenging and antigenotoxic activities of natural phenolic compounds in dried flowers of Hibiscus sabdariffa L. Mol Nutr Food Res, 49 (12), 1120-1128.

Frankel SS, Reitman S, Sonnenwirth AC (1970). Grandwohl's clinical laboratory methods and diagnosis. In: Reading CA, Glynn LE (Editors).7th Edition, 403-404, The C. V. Mosby Company, St Louis, USA.

Fustinoni-Reis AM, Arruda SF, Dourado LP, Cunha da MS, Siqueira E (2016). Tucum-Do-Cerrado (Bactris setosa Mart.) consumption modulates iron homeostasis and prevents iron-induced oxidative stress in the rat liver. Nutrients, 8 (2), 38.

Gaweł S, Wardas M, Niedworok E, Wardas $P$ (2004). Malondialdehyde (MDA) as a lipid peroxidation marker. Wiad Lek, 57 (9-10), 453-455.

Gayathri R, Priya DK, Gunassekaran GR, Sakthisekaran D (2009). Ursolic acid attenuates oxidative stress-mediated hepatocellular carcinoma induction by diethylnitrosamine in male Wistar rats. Asian Pac J Cancer Prev, 10 (5), 933-938.

Gupta P, Bansal PM, Koul A (2013). Lycopene modulates initiation of Nnitrosodiethylamine induced hepatocarcinogenesis: Studies on chromosomal abnormalities, membrane fluidity and antioxidant defense system. Chem Biol Interact, 206 (2), 364-374.

Habig WH, Pabst MJ, Jakoby WB (1974). Glutathione S-transferases. The first enzymatic step in mercapturic acid formation. J Biol Chem, 249 (22), 7130-7139.

Halliwell B, Gutteridge JM (2015). Free Radicals in Biology and Medicine. Oxford University Press, USA.

Jahan MS, Vani G, Shyamaladevi CS (2007). Effect of Solanum trilobatum on hepatic drug metabolising enzymes during diethylnitrosamineinduced hepatocarcinogenesis promoted by Phenobarbital in rat. Hepatol Res, 37 (1), 35-49.

Kaya E, Yılmaz S, Çeribaşı AO, Telo S (2019). Protective effect of lycopene on diethylnitrosamine-induced oxidative stress and catalase expression in rats. Ankara Üniv Vet Fak Derg, 66(1), 43-52.

Kim DJ, Takasuka N, Kim JM, et al. (1997). Chemoprevention by lycopene of mouse lung neoplasia after combined initiation treatment with DEN MNU and DMH. Cancer Lett, 120 (1), 15-22.

Kim S, Choi JE, Choi J, et al. (2009). Oxidative stress-dependent toxicity of silver nanoparticles in human hepatoma cells. Toxicol in Vitro, 23 (6),1076-1084.

Krinsky NI (1998). Overview of lycopene, carotenoids, and disease prevention. Proc Soc Exp Biol Med, 218 (2), 95-97.

Kumar P, Kumar A (2009). Effect of lycopene and epigallocatechin-3 gallate against 3-nitropropionic acid induced cognitive dysfunction and glutathione depletion in rat: a novel nitric oxide mechanism. Food Chem Toxicol, 47 (10), 2522-2530.
Lijinsky W (1992). Chemistry and Biology of N-nitroso Compounds. Cambridge, UK: Cambridge Univ. Pres.

Lijinsky W, Kovatch RM (1989). Carcinogenesis by nitrosamines and azoxyalkanes by different routes of administration to rats. Biomed Environ Sci, 2 (2), 154-159.

Liu LL, Gong LK, Q1 XM, et al. (2005). Altered expression of cytochrome p450 and possible correlation with preneoplastic changes in early stage of rat hepatocarcinogenesis. Acta Pharmacol Sin, 26 (6), 737-744.

Lowry OH, Rosenbrough NJ, Farr AL, Randall RJ (1951). Protein measurement with the folin-phenol reagent. J Biol Chem, 193, 265-257.

Luna LG (1968). Manuel of histologic staining methods of Armed Forces Institute of Pathology. 1-36, McGraw-Hill Book Co, New York.

Placer ZA, Cushman L, Johnson BC (1966). Estimation of products of lipid peroxidation in biological fluids. Anal Biochem, 16: 359-364.

Pradeep K, Mohan CVR, Gobianand K, Karthikeyan S (2007). Silymarin modulates the oxidant-antioxidant imbalance during diethylnitrosamine induced oxidative stress in rats. Euro J Pharmacol, 560 (2-3), 110-116.

Pradeep K, Raj Mohan CV, Gobianand K, Karthikeyan S (2010). Protective effect of Cassia fistula Linn. on diethylnitrosamine induced hepatocellular damage and oxidative stress in ethanol pretreated rats. Biol Res, 43 (1), 113-125.

Qu M, Nan X, Gao Z, et al. (2013). Protective effects of lycopene against methylmercury-induced neurotoxicity in cultured rat cerebellar granule neurons. Brain Res, 1540, 92-102.

Rotimi OA, Rotimi So, Duru CU, et al. (2017). Acute aflatoxin B1-Induced hepatotoxicity alters gene expression and disrupts lipid and lipoprotein metabolism in rats. Toxicol Rep, 4, 408-414.

Sayed-Ahmed MM, Aleisa AM, Al-Rejaie S, et al. (2010). Thymoquinone attenuates diethylnitrosamine induction of hepatic carcinogenesis through antioxidant signaling. Oxid Med Cell Longev, 3 (4), 254-261.

Shaarawy SM, Tohamy AA, Elgendy SM, et al. (2009). Protective effects of garlic and silymarin on NDEA-induced rats hepatotoxicity. Int J Biol Sci, 5 (6), 549-557.

Sun Y, Oberly LW, Ying LA (1988). Simple method for clinical assay of superoxide dismutase. Clin Chem, 34 (3), 497-500.

Taha MM, Abdul AB, Abdullah $R$, et al. (2010). Potential chemoprevention of diethylnitrosamine-initiated and 2acetylaminofluorene-promoted hepatocarcinogenesis by zerumbone from the rhizomes of the subtropical ginger (Zingiber zerumbet). Chem Biol Interact, 186 (3), 295-305.

Ukai N, Lu Y, Etoh H, et al. (1994). Photosensitized oxygenation of lycopene. Biosci Biotech Biochem, 58 (9), 1718-1719.

Yamada K, Yamamiya I, Utsumi H (2006). In vivo detection of free radicals induced by diethylnitrosamine in rat liver tissue. Free Radic Biol Med, 40 (11), 2040-2046.

Yılmaz S, Karahan İ, Kandemir FM (2008). Bazı nitrozaminlerin ratlarda doku pirüvat kinaz aktivitesi üzerine etkileri. F.Ü. Sağ Bil Derg, 22 (3), 163-168.

Yilmaz S, Atessahin A, Sahna E, Karahan I, Ozer S (2006). Protective effect of lycopene on adriamycin-induced cardiotoxicity and nephrotoxicity. Toxicology, 218 (2), 164-171. 